\title{
The Analysis of Students' Special Curiosity in Sports Based on Some Demographic Variables
}

\author{
Mehmet Yıldırım ${ }^{1}$, Oktay Çoban ${ }^{1}$ \\ ${ }^{1}$ Yozgat Bozok University, School of Physical Education and Sports, Yozgat, Turkey \\ Correspondence: Mehmet Yıldırım, School of Physical Education and Sports, Yozgat Bozok University, Yozgat, Turkey.
}

Received: December 27, 2018

Accepted: January 22, 2019

Online Published: January 29, 2019

doi:10.11114/jets.v7i3.3914

URL: https://doi.org/10.11114/jets.v7i3.3914

\begin{abstract}
The present study aims to determine special curiosity in sports among students who study at different university departments. The population of the study consists of students studying at different departments at Yozgat Bozok University during 2018-2019 academic year. The sample of the study consists of 397 students who study at different departments at Yozgat Bozok University during 2018-2019 academic year and voluntarily participated in the online survey sent them by e-mail. Survey was used as a data collection method in the study. Students' demographic features were obtained using a "personal information form". In order to identify students' specific curiosity in sports, "Sport Fan Specific Curiosity Scale" adapted to Turkish context and tested for reliability and validity by Korur and Dever (2018) was used. The obtained data were statistically analyzed using SPSS 18 software program. Frequency analysis, percentage analysis, arithmetic means, $t$ test and ANOVA were used for data analysis. The findings of the analysis demonstrate that statistically significant differences were found among students' levels of specific curiosity in sports in terms of their gender, department, family participation in sports and monthly expenses $(p<0.05)$. On the other hand, no statistically significant differences were observed among students in terms of place of residence and family level of income ( $\mathrm{p}>0.05)$.
\end{abstract}

Keywords: sports, curiosity, university, student

\section{Introduction}

Curiosity has always been present in human mind, and is considered to be necessary for a human being. An individual wishes to explore their surroundings from the birth. Curiosity allows people to seek for answers, explore various issues, observe their environment and understand ongoing events in the world. An increasing curiosity points to a higher chance of exploring for an individual (Korur, 2018).

The willingness to understand or learn something is defined as curiosity. Piaget (2005) regards curiosity as one of the most important elements that improves and broadens the body of knowledge. Maslow (1970), similarly, underlines the role of human beings' persisting curiosity in the scientific development. Although the definition of curiosity has been little discussed in the literature, it is evident that it has remained almost the same among many scholars over the centuries. Firstly, curiosity was considered as a motivated desire to reach information. Secondly, it was defined as a passion that indicates the density of a person's motivation. Finally, it was expressed as an appetite that needs to be satisfied (Loewenstein, 1994). Given the existence of various definitions for curiosity, it can be stated that all of them directly stem from a desire, passion or appetite to learn and know. Curiosity, which is the result of an attempt to understand and learn about the world, is also a point of departure for the emergence and continuation of scientific and technological developments (Ronan, 2003).

It is known that curiosity has so far led to the discovery of numerous things in history. It is also argued that it is one of the main reasons why sports and its branches were invented. According to Erişim (2006), sports influence all dimensions of human body and mind because of its certain characteristics such as peace, tolerance, equality, discipline, virtue, joy, love and respect as well as involving humanistic traits such as sadness, grief and stress. Students' cultural, socio-economic and personal traits or the existence of exemplary situations which will help them develop a positive attitude towards sports influence their participation in sports at different levels (Pepe and Kuru, 2001). When studies on the positive impact of sports on individuals' lives are analyzed, it can be noted that sports positively influence individuals' psychomotor development (Öngül et al., 2017), significantly improve their level of physical suitability, 
(Saygin et al., 2005), provide them with social and physical benefits (Özkara et al., 2016), enable students doing sports to attain higher academic success compared to those who do not (Şenses, 2009; Şenduran, 2006), increase students' self-confidence and help them cope with stress, and provide them with a more social and easy-going personality (Şenduran, 2006), and decrease their level of aggression (Bostanc1 et al., 2017).

Just as it plays a vital role in many fields, curiosity also occupies an important position in learning sports activities. Therefore, it is important to analyze the impact of curiosity on participation in sports activities. Individuals examine various events surrounding themselves with a sense of curiosity, and try to learn. It can be said that participation in sports among young people are directly related to the sense of curiosity (Cihan and Ilgar, 2018). It is of vital importance for state institutions to identify and support sports fields in which students studying at different departments are particularly interested and thus help them participate in these sports activities, which will increase their existing physical conditions to a higher level and contribute to their mental development as well. In addition, it is a wrong assumption that having an occupation which is not centered sports activities is not a reason for an individual's disinterest in sports. Participation in sports activities increases professional success, and provides individuals with the ability to perform an activity collectively. Thanks to sports, individuals gain a competitive personality, work discipline, courage and ambition to struggle. They teach them to accept winning and losing, sharing, helping, and respecting others' views and opinions. As a result of collaborative work, individuals develop their sense of social responsibility (Şahan, 2007). Therefore, it can be argued that it is crucial to reveal curiosity in sports and participation in sports among individuals who receive academic education and will continue their professional activities in different fields, which will also bring a new perspective to their pursuits in terms of sports activities.

\section{Method}

In this section, the population and sample of the study, data collection tools and statistical methods used for data analysis are described.

\subsection{Population and Sample of the Study}

The population of the study consists of students studying at different departments at Yozgat Bozok University during 2018-2019 academic year. The sample of the study consists of 397 students who study at different departments at Yozgat Bozok University during 2018-2019 academic year and voluntarily participated in the online survey sent them by e-mail.

\subsection{Data Collection Tools}

In the present study, survey, which is among primary sources of research, was used as a data collection tool because it is economic, feasible and allows researchers to easily collect information from large and dispersed masses within a short period of time. The questionnaire form used in the study was divided into two parts. In this respect, the first part identifies participants' personal and social features using limited items, whereas the second part benefits from "Sport Fan Specific Curiosity Scale" in order to identify students' specific curiosity in sports.

\subsubsection{Sport Fan Specific Curiosity Scale}

In order to measure students' specific curiosity in sports, "Sport Fan Specific Curiosity Scale", which was developed by Park, Ha and Mahony (2014) and adapted to Turkish context and tested for reliability and validity by Korur and Dever (2018), was used in the present study. This is a data collection tool with five sub-dimensions consisting of 11 items ranging from "1 (Strongly Disagree)" to "5 (Strongly Agree)". The sub-dimensions of the scale were named as specific information, general information and sport facility information, respectively. While the total reliability of the scale was calculated as .86 , the reliability of its sub-dimensions were calculated as $.90, .75$, and .71 , respectively.

In the present study, on the other hand, total reliability coefficient of the scale was measured as .92 , and the reliability of its sub-dimensions was measured as $.93, .85$ and .82 . A reliability coefficient between .70 and .90 represents a high level of reliability (Bagozzi and Yi, 1988; 76-94, Nunnally and Bernstein, 1994). Therefore, it can be seen that the scale meets the minimum requirement for its internal consistency reliability coefficients.

\subsection{Data Analysis}

The data obtained from the present study were analyzed using SPSS 18.0 package program. These data should be prepared and made suitable for statistical analysis beforehand. At this stage, skewness and kurtosis coefficients play a significant role (Şimşek, 2007; 74). A skewness coefficient of (+-2) and a kurtosis coefficient of (+-7) indicate a normal data distribution (West et al., 1995; Şencan, 2005; 376, Şimşek, 2007; 74). In the present study, the skewness and kurtosis coefficients of the data were calculated between $0.052 / 0.526$ and $-0.831 /-1.161$, respectively. Therefore, it was decided that the obtained data displayed a normal distribution, and parametric tests were used for statistical analysis. 
While frequency and percentage analysis were used to describe students' demographic features for the statistical analysis of the data obtained from the present study, $t$ test and ANOVA test were used to indicate differences among participants' level of specific curiosity in sports based on demographic variables. The level of statistical significance was taken as 0.05 .

\section{Results}

The findings related to students' demographic features are given in Table 1.

Table 1. Students’ Demographic Features

\begin{tabular}{|c|c|c|c|}
\hline & & $\mathrm{N}$ & $\%$ \\
\hline \multirow[t]{2}{*}{ Gender } & Male & 99 & 24.9 \\
\hline & Female & 298 & 75.1 \\
\hline \multirow[t]{2}{*}{ Department } & Faculty/School & 280 & 70.5 \\
\hline & Vocational School & 117 & 29.5 \\
\hline \multirow[t]{2}{*}{ Place of Residence } & City center & 288 & 72.5 \\
\hline & Town & 109 & 27.5 \\
\hline \multirow[t]{2}{*}{ Family Participation in Sports } & Yes & 151 & 38.0 \\
\hline & No & 246 & 62.0 \\
\hline \multirow[t]{5}{*}{ Family Level of Income } & $1600 \mathrm{TL}$ and less & 145 & 36.5 \\
\hline & $1601 \mathrm{TL}-3200 \mathrm{TL}$ & 161 & 40.6 \\
\hline & $3201 \mathrm{TL}-4800 \mathrm{TL}$ & 49 & 12.3 \\
\hline & $4801 \mathrm{TL}-6400 \mathrm{TL}$ & 30 & 7.6 \\
\hline & $6401 \mathrm{TL}$ and more & 12 & 3.0 \\
\hline \multirow[t]{2}{*}{ Monthly Expenses } & $750 \mathrm{TL}$ and less & 279 & 70.3 \\
\hline & 751 TL and more & 118 & 29.7 \\
\hline
\end{tabular}

When Table 1 is analyzed, it can be observed that 99 students (24.9\%) are males, while 298 students (75.1\%) are females. 280 students $(75.1 \%)$ study at a faculty or school, while $117(\% 29.5)$ of them study at a vocational school. 288 students $(72.5 \%)$ live in the city center, whereas 109 of them $(27.5 \%)$ live in town. In terms of family participation in sports, 151 students $(38.0 \%)$ responded 'yes', while 246 of them $(62.0 \%)$ said 'no'. The responses to the question about family level of income varied as $1600 \mathrm{TL}$ and less by 145 students (36.5\%), $1601 \mathrm{TL}-3200 \mathrm{TL}$ by 161 students (40.6\%), $3201 \mathrm{TL}-4800$ TL by 49 students (12.3\%), $4801 \mathrm{TL}-6400 \mathrm{TL}$ by 30 (7.6\%) students, and $6401 \mathrm{TL}$ and more by 12 students (3.0\%). When it comes to students' monthly expenses, 279 of them (70.3\%) spend 750 TL and less, while 118 of them $(29.7 \%)$ spend 751 TL and more on a monthly basis.

Mean sport fan specific curiosity scale sub-dimension scores and standard deviation values are given in Table 2.

Table 2. Mean sport fan specific curiosity scale sub-dimension scores and standard deviation values

\begin{tabular}{lccc}
\hline & $\mathrm{N}$ & $\overline{\mathrm{x}}$ & $\mathrm{Sd}$ \\
\hline Specific Information & 397 & 2.50 & 1.28 \\
\hline General Information & 397 & 3.35 & 1.19 \\
\hline Sport Facility Information & 397 & 2.98 & 1.30 \\
\hline
\end{tabular}

It can be understood from Table 2 that the most important sub-dimension of sport fan specific curiosity scale is general information $(\overline{\mathrm{x}}=3.35)$.

$\mathrm{t}$ test findings related to the comparison of mean sport fan specific curiosity scale sub-dimension scores in terms of gender are given in Table 3 .

Table 3. $\mathrm{t}$ test findings related to the comparison of mean sport fan specific curiosity scale sub-dimension scores in terms of gender

\begin{tabular}{|c|c|c|c|c|c|c|}
\hline & Gender & $\mathrm{N}$ & $\overline{\mathrm{x}}$ & $\mathrm{Sd}$ & $\mathrm{t}$ & $\mathrm{P}$ \\
\hline \multirow[t]{2}{*}{ Specific Information } & Male & 99 & 3.26 & 1.39 & \multirow[t]{2}{*}{7.173} & \multirow[t]{2}{*}{.000} \\
\hline & Female & 298 & 2.25 & 1.14 & & \\
\hline \multirow[t]{2}{*}{ General Information } & Male & 99 & 3.71 & 1.27 & \multirow[t]{2}{*}{3.554} & \multirow[t]{2}{*}{.000} \\
\hline & Female & 298 & 3.23 & 1.14 & & \\
\hline \multirow[t]{2}{*}{ Sport Facility Information } & Male & 99 & 3.47 & 1.30 & \multirow[t]{2}{*}{4.444} & \multirow[t]{2}{*}{.000} \\
\hline & Female & 298 & 2.81 & 1.27 & & \\
\hline
\end{tabular}

In Table 3, it can be understood that statistically significant differences were found among mean sport fan specific curiosity scale sub-dimension scores in terms of gender $(\mathrm{p}<.05)$. It was observed in all sub-dimensions that male students' levels of specific curiosity in sports were higher compared to female students. 
$\mathrm{t}$ test findings related to the comparison of mean sport fan specific curiosity scale sub-dimension scores in terms of department are given in Table 4.

Table 4. $\mathrm{t}$ test findings related to the comparison of mean sport fan specific curiosity scale sub-dimension scores in terms of department

\begin{tabular}{llllllc}
\hline & Department & $\mathrm{N}$ & $\overline{\mathrm{x}}$ & $\mathrm{Sd}$ & $\mathrm{t}$ & $\mathrm{P}$ \\
\hline Specific Information & Faculty/School & 280 & 2.64 & 1.33 & 3.670 & \multirow{2}{*}{.000} \\
\cline { 2 - 6 } & Vocational School & 117 & 2.17 & 1.10 & & \\
\hline General Information & Faculty/School & 280 & 3.45 & 1.19 & 2.591 & .010 \\
\cline { 2 - 6 } & Vocational School & 117 & 3.11 & 1.15 & & \\
\hline Sport Facility Information & Faculty/School & 280 & 3.07 & 1.29 & 2.257 & \multirow{2}{*}{.025} \\
\cline { 2 - 5 } & Vocational School & 117 & 2.75 & 1.31 & & \\
\hline
\end{tabular}

Table 4 indicates that statistically significant differences were observed among mean sport fan specific curiosity scale sub-dimension scores in terms of department $(\mathrm{p}<.05)$. It was found out in all sub-dimensions that students studying at a faculty/school had a higher level of specific curiosity in sports compared to those studying at a vocational school.

$\mathrm{t}$ test findings related to the comparison of mean sport fan specific curiosity scale sub-dimension scores in terms of place of residence are given in Table 5.

Table 5. $\mathrm{t}$ test findings related to the comparison of mean sport fan specific curiosity scale sub-dimension scores in terms of place of residence

\begin{tabular}{|c|c|c|c|c|c|c|}
\hline & Place of Residence & $\mathrm{N}$ & $\overline{\mathrm{x}}$ & $\mathrm{Sd}$ & $\mathrm{t}$ & $\mathrm{P}$ \\
\hline \multirow{2}{*}{ Specific Information } & City Centre & 288 & 2.51 & 1.31 & .182 & .856 \\
\hline & Town & 109 & 2.48 & 1.21 & & \\
\hline \multirow{2}{*}{ General Information } & City Centre & 288 & 3.40 & 1.19 & 1.297 & .195 \\
\hline & Town & 109 & 3.22 & 1.17 & & \\
\hline Sport Facility Information & City Centre & 288 & 2.99 & 1.32 & .186 & .852 \\
\hline
\end{tabular}

It is evident in Table 5 that no statistically significant differences were observed among mean sport fan specific curiosity scale sub-dimension scores in terms of place of residence ( $p>.05)$.

$\mathrm{t}$ test findings related to the comparison of mean sport fan specific curiosity scale sub-dimension scores in terms of family participation in sports are given in Table 6.

Table 6. $\mathrm{t}$ test findings related to the comparison of mean sport fan specific curiosity scale sub-dimension scores in terms of family participation in sports

\begin{tabular}{llllllc}
\hline & Family Participant in Sports & $\mathrm{N}$ & $\overline{\mathrm{x}}$ & $\mathrm{Sd}$ & $\mathrm{t}$ & $\mathrm{P}$ \\
\hline \multirow{2}{*}{ Specific Information } & Yes & 151 & 2.59 & 1.25 & 1.071 & .285 \\
\cline { 2 - 6 } & No & 246 & 2.45 & 1.30 & & \\
\hline \multirow{2}{*}{ General Information } & Yes & 151 & 3.55 & 1.15 & 2.651 & .008 \\
\cline { 2 - 6 } & No & 246 & 3.22 & 1.20 & & \\
\hline \multirow{2}{*}{ Sport Facility Information } & Yes & 151 & 3.12 & 1.34 & \multirow{2}{*}{1.678} & \multirow{2}{*}{.094} \\
\cline { 2 - 7 } & No & 246 & 2.89 & 1.28 & & \\
\hline
\end{tabular}

It can be seen in Table 6 that statistically significant differences were revealed among mean sport fan specific curiosity scale sub-dimension scores in terms of family participation in sports $(\mathrm{p}<.05)$. In the sub-dimension general information, it was observed that students whose families actively participated in sports had a higher level of specific curiosity in sports compared to those whose families did not.

ANOVA findings related to the comparison of mean sport fan specific curiosity scale sub-dimension scores in terms of family level of income are given in Table 7. 
Table 7. ANOVA findings related to the comparison of mean sport fan specific curiosity scale sub-dimension scores in terms of family level of income

\begin{tabular}{|c|c|c|c|c|c|c|c|c|c|c|c|}
\hline & Group & $\mathrm{N}$ & $\overline{\mathrm{x}}$ & $\mathrm{Sd}$ & $\begin{array}{l}\text { Source } \\
\text { Var. }\end{array}$ & of & $\begin{array}{l}\text { Sum of } \\
\text { Sq. }\end{array}$ & $\mathrm{df}$ & $\begin{array}{l}\text { Mean } \\
\text { Sq. }\end{array}$ & $\overline{\mathrm{F}}$ & $\overline{\mathrm{P}}$ \\
\hline \multirow[t]{5}{*}{$\begin{array}{l}\text { Specific } \\
\text { Information }\end{array}$} & $\begin{array}{l}1600 \mathrm{TL} \text { and } \\
\text { less }\end{array}$ & 145 & 2.38 & 1.22 & $\begin{array}{l}\text { Between } \\
\text { Groups }\end{array}$ & & 14.349 & 4 & 3.587 & \multirow[t]{5}{*}{2.202} & \multirow[t]{5}{*}{.068} \\
\hline & $\begin{array}{ll}1601 \mathrm{TL} & - \\
3200 \mathrm{TL} & \end{array}$ & 161 & 2.42 & 1.20 & $\begin{array}{l}\text { Within } \\
\text { Groups }\end{array}$ & & 638.569 & 392 & 1.629 & & \\
\hline & $\begin{array}{l}3201 \mathrm{TL}- \\
4800 \mathrm{TL}\end{array}$ & 49 & 2.91 & 1.51 & Total & & 652.918 & 396 & & & \\
\hline & $\begin{array}{l}4801 \text { TL }- \\
6400 \mathrm{TL}\end{array}$ & & 2.72 & 1.35 & & & & & & & \\
\hline & $\begin{array}{l}6401 \mathrm{TL} \text { and } \\
\text { more }\end{array}$ & 12 & 2.83 & 1.54 & & & & & & & \\
\hline \multirow[t]{5}{*}{$\begin{array}{l}\text { General } \\
\text { Information }\end{array}$} & $\begin{array}{l}1600 \mathrm{TL} \text { and } \\
\text { less }\end{array}$ & & 3.33 & 1.16 & $\begin{array}{l}\text { Between } \\
\text { Groups }\end{array}$ & & 5.623 & 4 & 1.406 & \multirow[t]{5}{*}{.984} & \multirow[t]{5}{*}{.416} \\
\hline & $\begin{array}{l}1601 \mathrm{TL} \\
3200 \mathrm{TL}\end{array}$ & 161 & 3.25 & 1.20 & $\begin{array}{l}\text { Within } \\
\text { Groups }\end{array}$ & & 559.894 & 392 & 1.428 & & \\
\hline & $\begin{array}{l}3201 \mathrm{TL} \\
4800 \mathrm{TL}\end{array}$ & 49 & 3.49 & 1.18 & Total & & 565.518 & 396 & & & \\
\hline & $\begin{array}{l}4801 \text { TL }- \\
6400 \mathrm{TL}\end{array}$ & 30 & 3.53 & 1.19 & & & & & & & \\
\hline & $\begin{array}{l}6401 \mathrm{TL} \text { and } \\
\text { more }\end{array}$ & 12 & 3.77 & 1.40 & & & & & & & \\
\hline \multirow[t]{5}{*}{$\begin{array}{l}\text { Sport Facility } \\
\text { Information }\end{array}$} & $\begin{array}{l}1600 \mathrm{TL} \text { and } \\
\text { less }\end{array}$ & 145 & 2.89 & 1.29 & $\begin{array}{l}\text { Between } \\
\text { Groups }\end{array}$ & & 5.597 & 4 & 1.399 & \multirow[t]{5}{*}{.815} & \multirow[t]{5}{*}{.516} \\
\hline & $\begin{array}{l}1601 \mathrm{TL}- \\
3200 \mathrm{TL}\end{array}$ & 161 & 2.94 & 1.27 & $\begin{array}{l}\text { Within } \\
\text { Groups }\end{array}$ & & 672.957 & 392 & 1.717 & & \\
\hline & $\begin{array}{l}3201 \mathrm{TL} \\
4800 \mathrm{TL}\end{array}$ & 49 & 3.25 & 1.32 & Total & & 678.554 & 396 & & & \\
\hline & $\begin{array}{l}4801 \text { TL }- \\
6400 \mathrm{TL}\end{array}$ & & 3.10 & 1.42 & & & & & & & \\
\hline & $\begin{array}{l}6401 \mathrm{TL} \text { and } \\
\text { more }\end{array}$ & 12 & 3.11 & 1.61 & & & & & & & \\
\hline
\end{tabular}

${ }^{*} \mathrm{p}<.05,{ }^{* *} \mathrm{p}<.01$

It can be observed in Table 7 that no statistically significant differences were found among mean sport fan specific curiosity scale sub-dimension scores in terms of family level of income ( $\mathrm{p}>.05)$.

$\mathrm{t}$ test findings related to the comparison of mean sport fan specific curiosity scale sub-dimension scores in terms of monthly expenses are given in Table 8.

Table $8 . \mathrm{t}$ test findings related to the comparison of mean sport fan specific curiosity scale sub-dimension scores in terms of monthly expenses

\begin{tabular}{|c|c|c|c|c|c|c|}
\hline & Monthly Expenses & $\mathrm{N}$ & $\overline{\mathrm{x}}$ & $\mathrm{Sd}$ & $\mathrm{t}$ & $\mathrm{P}$ \\
\hline \multirow[t]{2}{*}{ Specific Information } & $750 \mathrm{TL}$ and less & 279 & 2.38 & 1.24 & \multirow[t]{2}{*}{-2.880} & \multirow[t]{2}{*}{.004} \\
\hline & $751 \mathrm{TL}$ and more & 118 & 2.78 & 1.32 & & \\
\hline \multirow[t]{2}{*}{ General Information } & $750 \mathrm{TL}$ and less & 279 & 3.27 & 1.18 & \multirow[t]{2}{*}{-1.879} & \multirow[t]{2}{*}{.061} \\
\hline & 751 TL and more & 118 & 3.52 & 1.21 & & \\
\hline \multirow[t]{2}{*}{ Sport Facility Information } & $750 \mathrm{TL}$ and less & 279 & 2.86 & 1.27 & \multirow[t]{2}{*}{-2.762} & \multirow[t]{2}{*}{.006} \\
\hline & $751 \mathrm{TL}$ and more & 118 & 3.25 & 1.35 & & \\
\hline
\end{tabular}

It is clear in Table 8 that statistically significant differences were observed between mean specific information and sport facility information scores in terms of monthly expenses $(p<.05)$. It was found out that students who had a higher amount of monthly expenses in the sub-dimensions of specific information and sport facility information had a higher level of specific curiosity in sports.

\section{Discussion}

The findings in the present study demonstrate that there were statistically significant differences among mean sport fan specific curiosity scale scores in terms of gender. In all sub-dimensions, it was revealed that male students' levels of specific curiosity in sports were higher compared to female students.

Türkmen et al. (2016) reported statistically significant differences between female and male students. Akandere et al. 
(2010), too, found significant differences between female and male students. Smoll and Schutz (1980) indicated that male students were more positive towards physical education and sports compared to female students. Özyalvaç (2010) observed significant differences between female and male students in terms of physical education and sports as a subject. Tomik et al. (2012) demonstrated in their study on students that male students' attitude towards physical education and sports were more positive compared to that of female students. Similarly, Koçak (2014) revealed a significant difference between female and male students. The findings of these studies overlap those in the present study. However, Göksel et al. (2017) did not report any significant differences between female and male university students. In a similar vein, İlhan and Gencer (2013) observed no significant differences between female and male students. Zengin et al. (2016) did not find any significant differences between female and male students, either. Therefore, these three studies do not overlap the findings of the present study in terms of gender as a variable.

In terms of department as a variable, statistically significant differences were observed among mean sport fan specific curiosity sub-dimension scores. It was found out in all sub-dimensions that students studying at a faculty/school had a higher level of specific curiosity in sports compared to those who study at a vocational school. Zengin et al. (2016) also reported a significant difference among students in terms of their school type, which is similar to the present study.

As for family level of income, no statistically significant differences were observed among mean sport fan specific curiosity sub-dimension scores. Similarly, Türkmen et al. (2016) reported no significant differences among students in terms of family level of income. Özyalvaç (2010) also found no significant differences among students with different levels of income in their families. It is evident that these studies overlap the results of the present study.

\section{Conclusion}

The analysis in the present study indicates that the data display a normal distribution. In addition, the most important sub-dimension of sport fan specific curiosity scale was general information.

When analyzed from the viewpoint of gender, statistically significant differences were observed among mean sport fan specific curiosity scale sub-dimension scores. However, it was observed in all sub-dimensions that male students had a higher level of specific curiosity in sports compared to female students. It can be argued that male students' strong physical and muscular structures and higher interest in sports lead to such a difference.

When it comes to the department as a variable, statistically significant differences were found among mean sport fan specific curiosity scale sub-dimension scores. It was found out in all sub-dimensions that students who study at a faculty/school had a higher level of specific curiosity in sports compared to those who study at a vocational school. This difference can be attributed to the greater role of sport classes at faculties and schools compared to vocational schools.

In terms of place of residence, no statistically significant differences were observed among mean sport fan specific curiosity scale sub-dimension scores. Therefore, it can be deduced from this finding that the location where students live do not significantly influence their curiosity in sports.

As for students' family members' participation in sports, statistically significant differences were reported among mean sport fan specific curiosity scale sub-dimension scores. However, it was also found out that family participation in sports was directly proportional to a higher level of specific curiosity in sports among students. This finding indicates that family is an important factor for a student's level of specific curiosity in sports.

When the findings are analyzed in terms of family level of income, it can be seen that no significant differences existed among mean sport fan specific curiosity scale sub-dimension scores. Therefore, it can be stated that students' family level of income was not a significant factor as all students need to have a specific curiosity in sports.

Finally, concerning students' monthly expenses, significant differences were observed between mean scores in the sub-dimensions of specific information and sport facility information. It was observed in these sub-dimensions that students who had a high amount of monthly expenses also had a higher level of specific curiosity in sports. Spending a high amount of money is closely related to monthly level of income. Therefore, if students do not suffer financial problems, they are more likely to have a high curiosity and interest in sports.

\section{References}

Akandere, M., Özyalvaç, N. T., \& Duman, S. (2010). The Attitudes of the Students in Secondary Education to Physical Education Lesson and the Investigation of Their Success Motivations (Konya Anatolian High School Sample). Selçuk University the Journal of Institute of Social Science, 24, 1-10.

Bagozzi, R. P., \& Yi, Y. (1988). On the evaluation of structural equation models, Academy of Marketing Science, 16(1), 76-94. https://doi.org/10.1007/BF02723327

Bostancı, Ö., Oda, B., Kenan, Ş., \& Erail, S. (2017). Investıgation of the level of aggression and optımısmon the students aged 11-13 who do sports or not, Atatürk University Journal of Physical Education and Sport Sciences, 
19(4), 205-217.

Cihan, B. B., \& Ilgar, A. E. (2018). Determining The Curiosity Level Of High School Students Who Do Sports And Who Do Not (Sedentary), Ahi Evran University Journal of Kirşehir Education Faculty, 19(2), 1649-1660.

Erişim, C. (2006). Sports, olympics, morality and fair play, socially sporting. It was accessed on 12.10.2018 at www.sporbilim.com.

Göksel, A. G., Caz, Ç., Yazıcı, Ö. F., \& İkizler, H. C. (2017). Comparison Of Attitudes Of Students From Different Departments Towards Sport: The Model Of Marmara University. Journal of Sports and Performance Researches. $8(2), 123-134$.

İlhan, L., \& Gencer, E. (2013). Determination of Participation Motivation of High School AthleteStudents that Participated in Badminton Competition. Gazi Journal of Physical Education and Sport Sciences, 18(1-4), 1-6.

Koçak, F. (2014). Undergraduate students's attıtudes towards sport: a scale development study. Ankara University Faculty of Sport Sciences, 12(1), 59-69.

Korur, E. N., \& Dever, A. (2018). The valıdity and reliability of Turkısh version of sport fan specific curiosity scale, The Journal of Academic Social Science, 6(73), 219-227.

Loewenstein, G. (1994). The Psychology of Curiosity: A Review and Reinterpretation, Psychological Bulletin, 116(1), 75-98. https://doi.org/10.1037/0033-2909.116.1.75

Maslow, A. H. (1970). Motivation and Personality, Newyork: Harper \& Row Pub.

Nunnally, J. C., \& Bernstein, I. H. (1994). Psychometric Theory, Newyork: McGraw.

Öngül, E., Bayazıt, B., Yılmaz, O., \& Güler, M. (2017). The effect on the selected motoric characteristics of children in the game and physical activities lesson, Journal of Sport Sciences Researches, 2(1), 45-52.

Özkara, A. B., Kalkavan, A., Alemdağ, S., \& Alemdağ, C. (2016). The role of physical activity in psychological resilience. Baltic Journal of Sport \& Health Sciences, 3(102), 24-29.

Özyalvaç, N. T. (2010). The Evaluation of the Attitudes of Secondary School Students towards Physical Education Course and Academic Achievement Motivations (Example of Konya Anatolian High School). Master's Thesis, Selçuk University Institute of Health Sciences, Konya.

Park, S. H., Ha, J. P., \& Mahony, D. (2014). Development And Validation of a Measure of Sport Fans' Specific Curiosity, Journal of Sport Management, 28(6), 621-632. https://doi.org/10.1123/jsm.2013-0198

Pepe, H., \& Kuru, E. (2001). Investigation of socio-economic levels of women who do sports and not. Gazi Journal of Education Faculty, 21(3), 209-221.

Piaget, J. (2005). The Language and Thought of the Child, Routledge, New York. https://doi.org/10.4324/9780203992739

Ronan, C. A. (2003). History of Science History and Development of Science in World Cultures, Translated by: E. İhsanoğlu - F. Gunergun. Ankara: Tubitak Publications.

Şahan, H. (2007). Role of sports activities in socialization process of university students, Doctorate Thesis, Selçuk University Institute of Social Sciences, Konya.

Saygin, Ö., Polat, Y., \& Karacabey, K. (2005). The effects of movement training, applied to children on their physical fitness parameters, Firat University Journal of Health Sciences, 19(3), 205-212.

Şencan, H. (2005). Sosyal ve Davranışsal Ölçümlerde Güvenilirlik ve Geçerlik. Ankara: Seçkin Publications.

Şenduran, F. (2006). Ability to solve problems of athletes and non-athletes in military high schools, ability to resist stress, adaptability and success levels, Doctorate Thesis, Marmara University, Istanbul.

Şenses, M. (2009). Comparison of school lesson achievements of students who are 7th and 8th grade students of athletes and non-athletes in some primary schools in Trabzon. Master's Thesis, Karadeniz Teknik University, Trabzon.

Şimşek, O. F. (2007). Introduction to Structural Equation Modeling, Basic Principles and Applications of Lisrel. Ankara: Ekinoks Publications.

Smoll, F. L., \& Schutz, R. W. (1980). Children Attitudes Toward Physical Activity. A Longitudinal Analysis, Journal of Sport Psychology, 2, 137-147. https://doi.org/10.1123/jsp.2.2.137

Tomik, R., Olex-Zarychta, D., \& Mynarski, W. (2012). Social Values Of Sport Participation And Their Significance For 
Youth Attitudes Towards Physical Education And Sport, Studies In Physical Culture And Tourism, 19(2), 99-104.

Türkmen, M., Abdurahimoğlu, Y., Varol, S., \& Gökdağ, M. (2016). The Attitudes of the Students Attending to Faculty of Islamic Sciences towards Sports (The Sample of Bartın University), International Journal of Contemporary Educational Studies (Intjces), 2(1), 48-59.

West, S. G., Finch, J. F., \& Curran, P. J. (1995). Structural Equation Models with Nonnormal Variables and Remedies. Akt: Hoyle, R.H. (Ed.) (1995). Structural Equation Modeling: Concepts, Issues and Applications, Sage: London.

Zengin, S., Hekim, M., \& Hekim, H. (2016). An investigation of the attitudes of the secondary and high school students towards physical education lesson based on gender and education level variables. Journal of Human Sciences, 13(2), 3242-3251. https://doi.org/10.14687/jhs.v13i2.3944

\section{Copyrights}

Copyright for this article is retained by the author(s), with first publication rights granted to the journal.

This is an open-access article distributed under the terms and conditions of the Creative Commons Attribution license which permits unrestricted use, distribution, and reproduction in any medium, provided the original work is properly cited. 